\title{
First report of twig blight of ban tulsi (Croton bonplandianus Bail.) caused by Choanephora cucurbitarum (Berk. \& Ravenel) Thaxt. in India
}

\author{
Siddhartha Das, Subrata Dutta*, Sujit Kumar Ray \\ Department of Plant Pathology, Bidhan Chandra Krishi Viswa Vidyalaya, Mohanpur, Nadia, West Bengal 741252, India
}

Vol. 57, No. 4: 441-446, 2017

DOI: 10.1515/jppr-2017-0049

Received: July 14, 2017

Accepted: October 7, 2017

*Corresponding address:

subratadutta1972@gmail.com

\begin{abstract}
In August 2015, twig blight disease of ban tulsi (Croton bonplandianus Bail.) caused by Choanephora cucurbitarum (Berk. \& Ravenel) Thaxt. was observed for the first time, in the Gangetic alluvial region of West Bengal, India. A severe disease incidence (40-50\%) showed twig blight symptoms starting with shoot apical meristem (SAM), leaf, and blossom blight symptoms. Typical symptoms were characterized by over-projecting black pin head like emerging sporangiola which formed mycelial cushion on the infected surface. The present report describes the identification of the causal pathogen as C. cucurbitarum based on its morphology and the internal transcribed spacer of its ribosomal DNA (rDNA - ITS) sequences with $100 \%$ identity of NCBI-GenBank published Choanephora database. Optimum temperatures, $28-30^{\circ} \mathrm{C}$, coupled with high relative humidity $(80-90 \%)$ during the monsoon season enhances the disease's progress. To the best of our knowledge this is the first report of twig blight of C. bonplandianus, caused by C. cucurbitarum, in India as well as globally.
\end{abstract}

Key words: ban tulsi, Choanephora cucurbitarum, Croton bonplandianus, sporangiola, twig blight, India

\section{Introduction}

Croton bonplandianus Bail. (Euphorbiaceae) commonly known as "ban tulsi" is a perennial herb. It is a rich bioresource in of folk medicine and traditional ayurvedic medicine as well as the pharmaceutical industry as an ingredient of modern synthetic drugs. It is a native of South America and was first reported in India during the late 1890's (Kaul 1967). According to the World Health Organization (WHO 2001) 60\% of the world's population depend on traditional medicine, and $80 \%$ of the population in developing countries depend almost entirely on traditional medicinal practices, especially herbal medicine, for their primary health care needs (Fransworth 1994). The long tradition of herbal medicine can still be found in present day China, India, and many other countries (Kong et al. 2003; Tapsell 2006). This lactiferous herb grows up to 1-2 $\mathrm{ft}$ and is a major source of secondary metabolites including alkaloids, terpenoids and toxic components like phorbol esters (Phillipson 1995) $3 \alpha$ hydroxy-urs-12,15-dien, oleanoic acid, ursolic acid, $\beta$-sitosterol (Ghosh et al. 2013), norcinoacutine and a new alkaloid 3-methoxy-4,6 dihydroxy morphinandien-7-one (Tiwary et al. 1981). Even though C. bonplandianus has played such an important role in the Indian ethnomedicinal context, the emerging pathogen Choanephora cucurbitarum with severe twig blight symptoms was reported by our present investigation.

\section{Materials and Methods}

\section{Isolation and morphometric characterization of the causal pathogen}

Isolation of the pathogen was done by using three different strategies: i) placing small pieces $(5 \times 5 \mathrm{~mm})$ 
of infected tissue of ban tulsi on potato dextrose agar (PDA) medium (Saroj et al. 2012). Surface sterilization was carried out with $1 \% \mathrm{NaOCl}$ for $1 \mathrm{~min}$; ii) plucking the over projecting sporangiola from infected tissue surface (by using sterile fine forceps) and placed onto PDA; iii) single spore isolation strategy - in which 4-5 mature sporangiola mixed with 5-10 $\mu \mathrm{l}$ of sterile water in Eppendorf tubes and vortexed thrice for two minutes each. Vortexing was needed for breaking the sporangial wall and mixing sporangiospores into the sterile water. One $\mu \mathrm{l}$ of spore suspension was poured onto a plate with PDA and spread properly with spreader. Individual fungal colonies appeared in Petri dishes after $24 \mathrm{~h}$. To obtain pure colonies, particular pure colonies were selected to be transferred. The optimum temperature range for mycelial growth of the fungus was $28 \pm 2^{\circ} \mathrm{C}$.

\section{Molecular identification of the causal pathogen}

After completing morphological characterization, the causal pathogen was further processed for molecular detection at its genetic level. Molecular detection of isolate C.B-18 was confirmed by CTAB DNA extraction method (Doyle and Doyle 1987). Molecular identification of fungus was performed using sequencing of internal transcribed spacers (ITS) regions, due to the large ITS data collection for fungi, the extremely variable nature within highly conserved ribosomal coding sequences and the high popularity of studies dealing with fungal identification and phylogenetic relationships (Boysen et al. 1996). The ITS region turned out to be an appropriate barcoding marker in Mucorales (Walther et al. 2013). Internal transcribed spacers of the ribosomal DNA of C.B-18 isolate were amplified by using the primer pair ITS- 1 and ITS- 4 (White et al. 1990). Amplification was performed with BIORAD My Cycler ${ }^{\mathrm{TM}}$ thermal cycler (Bio Rad, USA), where the final reaction mixture was prepared with $2.5 \mu \mathrm{l}$ of 10x Taq buffer containing $15 \mathrm{mM} \mathrm{MgCl}$, $1.0 \mu \mathrm{l}$ of ITS1 primer $\left(5\right.$ picomolar $\left.\cdot \mu^{-1}\right), 1.0 \mu \mathrm{l}$ of ITS-4 primer ( 5 picomolar $\left.\cdot \mu^{-1}\right), 1 \mu \mathrm{l}$ of $25 \mathrm{mM}$ dNTP mix each, $1.5 \mathrm{U}$ of Taq polymerase $\left(3 \mathrm{U} \cdot \mu \mathrm{l}^{-1}\right), 16 \mu \mathrm{l}$ sterile distilled water and $3 \mu \mathrm{l}\left(20-30 \mathrm{ng} \cdot \mathrm{ul}^{-1}\right)$ of sample DNA, under the following cycling times: $3 \mathrm{~min}$ at $95^{\circ} \mathrm{C}, 35$ cycles $30 \mathrm{~s}$ at $95^{\circ} \mathrm{C}, 30 \mathrm{~s}$ at $50^{\circ} \mathrm{C}$, extension for $1 \mathrm{~min} 72^{\circ} \mathrm{C}$, with a final extension of $10 \mathrm{~min}$ at $72^{\circ} \mathrm{C}$. Amplified PCR products were observed in 1.5\% agarose gel in 1X TAE buffer and visualized under gel document unit (Bio Rad, USA) with ethidium bromide staining technique. The amplified $556 \mathrm{bp}$ product was sequenced by SciGenom pvt limited and submitted in NCBI, Genbank database with BLAST searching tool.

\section{Phylogenetic analysis}

A phylogenetic tree was inferred from analysis of ITS sequences using neighbour - joining method (among the closely related taxa of different countries derived from NCBI-Gen Bank Ch. cucurbitarum data base), by MEGA version 6 (Tamura et al. 2013).

\section{Pathogenicity test}

The pathogenicity was established by using two different techniques: detached twig assay and spraying of the spore suspension. In the first technique, a $40 \times 25 \mathrm{~cm}^{2}$ plastic tray was used as conserve system (to conserve microclimate moisture level), in which 7-8 $\mathrm{cm}$ long detached twig portions (for three sets) were kept on three inversely placed Petri plates $(9 \mathrm{~cm})$. A 3\% sucrose solution was poured onto the lower plate of each set for minimum nutrient uptake of the twig part during in vitro study. Basement of the whole system (plastic tray) was sandwiched with bilayer moist blotting paper-absorbent cotton layers. Of the three sets, one was used as a control and the other two were inoculated with two different isolates. A pre-grown single mycelial disc of two different isolates (C.B-16 and C.B-18) was attached $2-3 \mathrm{~cm}$ below at a pre-wounded (notched with a finely pointed sterile needle) shoot apical meristem of the cut twig portion. The inoculation site along with the mycelial disc was coiled with a thin film of moist absorbent cotton. The whole system or tray was covered with transparent polythene sheets with numerous pores (for aeration) and incubated at $28 \pm 2^{\circ} \mathrm{C}$ and $80-90 \%$ relative humidity in a growth chamber. In the second technique, five 30-day-old potted seedlings were taken for spraying of with spore suspension $\left(1 \times 10^{6}\right.$ spores $\cdot \mathrm{ml}^{-1}$ in sterile distilled water) method. Spore suspension concentration maintained as par Das et al. (2017). Among the five seedlings one was used as a control and the other four were treated with four different isolates (C.B-18 - ban tulsi, LP-12 - dolichos bean, C.B-16 - ban tulsi, Cow-1 cowpea). Treated and control plants were consecutively sprayed with spore suspension and sterile distilled water and finally covered with polythene bags and retained in the growth chamber as mentioned in the first technique.

\section{Results}

\section{Twig blight disease syndrome on ban tulsi}

In August-September 2015 through 2016, twig blight of C. bonplandianus caused by C. cucurbitarum was observed for the first time on 'C' farm of Bidhan Chandra Krishi Viswavidyalaya and Kalyani $\left(22.9751^{\circ} \mathrm{N}\right.$, 
$88.4345^{\circ} \mathrm{E}$ ) region of West Bengal, India with a $40-50 \%$ disease incidence level. Later the same disease infestation was recorded in several other districts of West Bengal, India. Symptoms primarily appeared on any susceptible part (leaf, blossom, stem, fruit) of the shoot system with water soaked lesions. Infected chlorophyllus tissue turned brownish, and leaf, blossom and shoot apical meristem (SAM) blight together constituted typical twig blight symptoms (Fig. 1A, B, C). Black pin head like emerging sporangiola (Fig. 2A) formed a cushiony appearance from the infected part. This investigation was aimed at isolating and identifying the pathogen responsible for twig blight disease of ban tulsi in India.

\section{Cultural and morphometric characterization of the pathogen}

A total of 30 isolates of the fungus were collected from diseased parts of Croton. Isolate C.B-18 was the most virulent, however no mycological differences were found between the isolates. Fungal culture was maintained in PDA (Fig. 2B). Morphological studies were
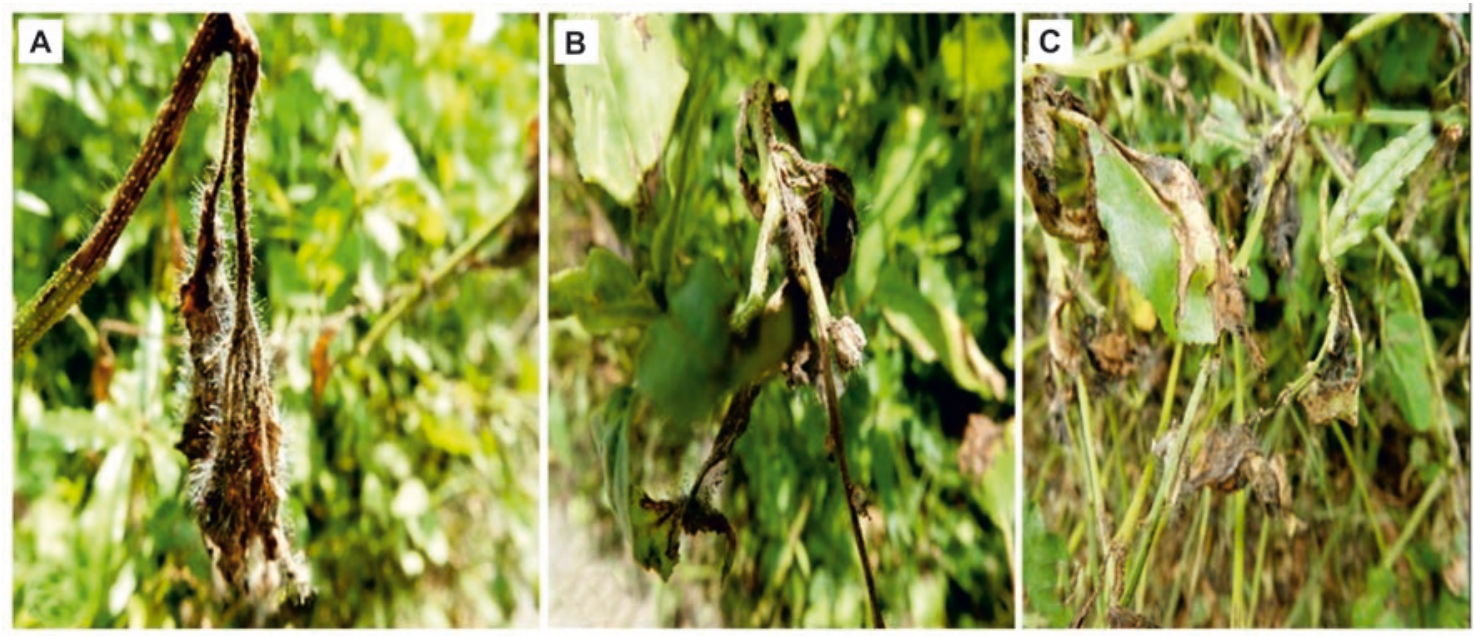

Fig. 1. Twig blight symptoms on Croton bonplandianus: A - apical stem; B - fruit; C - leaf


Fig. 2. A - emerging sporangiola of Choanephora cucurbitarum from host surface; B - culture on potato dextrose agar (PDA); $C$ - single sporangiola; D - sporangiospores 
based on morphometric characterization of the present isolate C.B-18 (Fig. 2C, D) with a comparative study with C. cucurbitarum (Kwon and Hyeong 2005). There was not much cultural differentiation found among all the isolates collected from different geographical regions as well as different hosts. Mycelia were aseptate and hyaline in nature. Full growth and appearance of cultural sporangiola, of the pathogen was recorded after 48 h. Creamish white coloured culture shows yellow pigmentation at maturity due to $\beta$-carotene synthesis. Morphologically sporangiophores bearing sporangiola (Fig. 2C) were hyaline, unbranched, apically dilated to form a clavate vesicle from which arose dichotomously branched, distally placed, secondary vesicles. Sporangiola were elliptic or ovoid, sub-globose sporangium, sporangiospores (Fig. 2D) were elliptic, fusiform, or ovoid in shape. The representative isolate C.B-18 and herbarium sample were deposited in NFCCI (National Fungal Culture Collection) and AMH (Ajrekar Mycological Herbarium) at ARI (Agharkar Research Institute), Pune, and assigned with accession nos. - NFCCI NO - 4074 and AMH - 9831.

\section{Pathogenicity test}

With the single mycelial disc inoculation strategy both of the host specific isolates (C.B-16 and C.B-18) showed pathogenicity and $4-5$ days post-inoculation (Fig. 3 ). In the study of spraying of spore suspension all the treated isolates showed pathogenicity, but we selected the host specific isolates for greater virulence because there was more damage according to Sinclair (1997), 0-9 point scale, than the other two. Pathogenicity tests showed similar symptoms under field conditions. Symptoms developed 7-8 days post-inoculation. Koch's postulate was established by conducting the pathogenicity test twice, with the re-isolation of the same pathogen in culture media.

\section{Molecular detection and phylogenetic analysis of the pathogen}

A GenBank blast search of the publicly available fungal database showed that the $556 \mathrm{bp}$ sequence of ITS - rDNA region exactly matches the C. cucurbitarum databases (JN 943007, and AB470641) with 100\% similarity. The resulting 556 bp DNA was deposited in GenBank and assigned accession number KX462163. Results revealed that, isolate KX462163 and C. cucurbitarum (JN943007 - USA, AB470641 - Japan) were conspecific on the same branch node and the highest similarity was found between them. The nearest clusture and closest taxa were found to be C. infundibulifera (KR867732 - Korea, KJ486539 - Korea, JN943009 - USA, AB470643 - Japan, JN206238 - Netherlands) from the same ancestral origin with $94 \%$ bootstrap value support (Fig. 4).

\section{Discussion}

Based on morphological, cultural characterization, molecular detection and by fulfilling the Koch's postulate, the isolated pathogen was identified as C. $\mathrm{cu}$ curbitarum (Berk. \& Ravenel) Thaxt. Morphometric specification was compared with C. cucurbitarum (Kwon and Hyeong 2005) (Table 1). The chemical constituents along with its splendid medicinal value are very important in the present agro-economical context of India, and in pharmaceutical and ayurvedic industies. Although, C. cucurbitarum has a

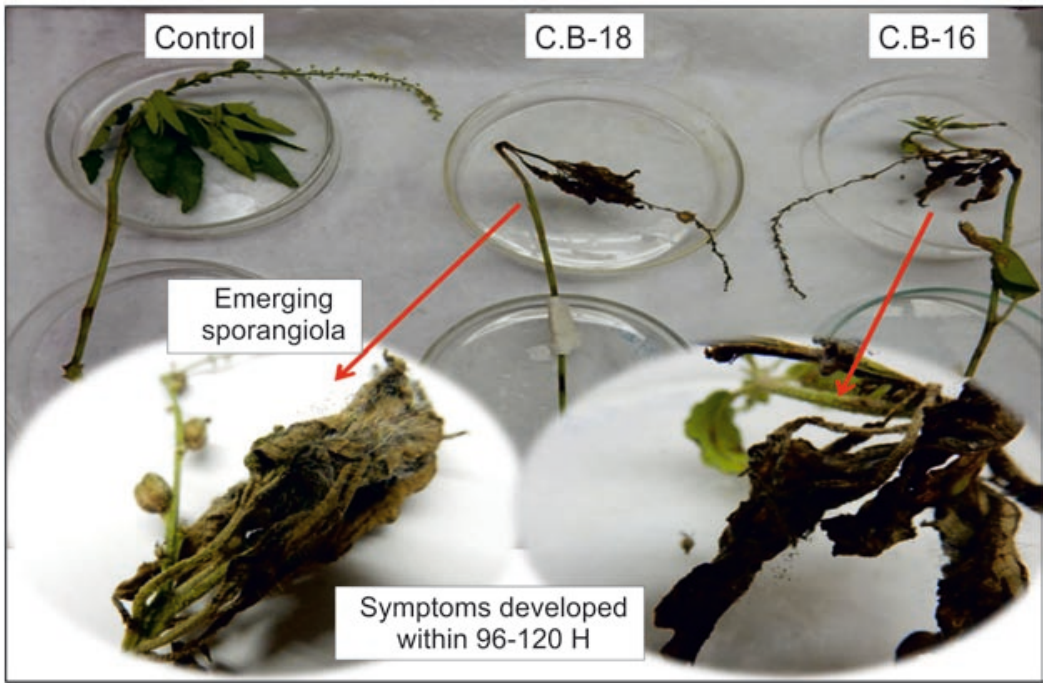

Fig. 3. Pathogenicity test conducted by single mycelial disc inoculation technique, with two different isolates: C.B-18 and C.B-16 of Choanephora cucurbitarum 


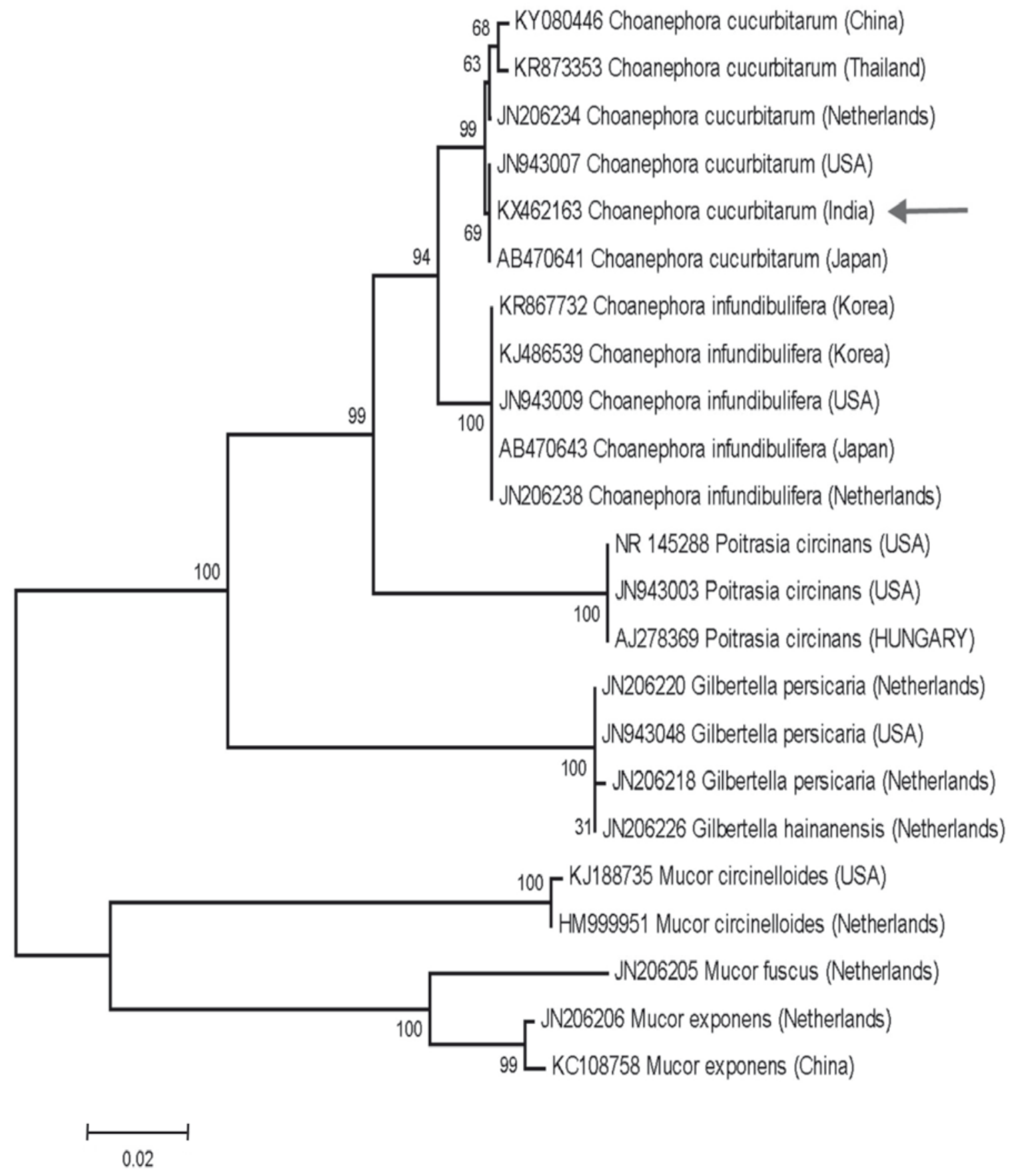

Fig. 4. Molecular phylogenetic analysis (ITS-r DNA) of Choanephora cucurbitarum with closely related taxa obtained from Genbank by neighbor-joining tree followed maximum composite likelihood method. The nodal significance was evaluated by means of bootstrapping performed using 1,000 replicates. Sequence obtained in the present study is marked by $(\leftarrow)$ symbol

wide host range it has not been previously reported to cause disease on Croton bonplandianus. Previously it was known that plant pathogenic zygomycetes are weak parasites (Agrios 2005), but some zygomycetous fungi evolved their behavior in such a way that their complex adaptability prefers new host ranges as a substitution of their trend line. The zygomycetous monster C. cucurbitarum enhances its specific domain activity day by day in the Gangetic alluvial region, and has turned out to be a serious threat to the vegetable cultivars and on various other crops. Optimum temperatures $\left(28-30^{\circ} \mathrm{C}\right)$ with a high moisture $(80-90 \%)$ level enhance diseaseprogress. However, suppressive factors like adequate airflow or a dry plant canopy can check the disease progress. This report is significant because it adds a new disease index to both plant pathology and the pharmacological industry. To the best of our knowledge and based on the literature, this is the first report of C. cucurbitarum causing twig blight of C. bonplandianus, in India as well as globally. 
Table 1. Mycological comparison between the causal pathogen (C.B-18) of twig blight of Croton bonplandianus and Choanephora cucurbitarum

\begin{tabular}{|c|c|c|c|}
\hline Morphology & Type & Isolate C.B-18 & C. curbitarum ${ }^{* *}$ \\
\hline \multirow{2}{*}{ Sporangium } & shape & subglobose, aseptate & subglobose, aseptate \\
\hline & size & $30-150 \mu \mathrm{m}$ & $40-130 \mu \mathrm{m}$ \\
\hline \multirow[t]{2}{*}{ Sporangiospore } & shape & $\begin{array}{l}\text { brown, elliptic, fusiform, ovoid, } \\
\text { having appendages, striate }\end{array}$ & $\begin{array}{l}\text { brown, elliptic, fusiform, ovoid, } \\
\text { having appendages, striate }\end{array}$ \\
\hline & size & $10-26.5 \times 5-12.5 \mu \mathrm{m}$ & $14-20 \times 7-16 \mu \mathrm{m}$ \\
\hline \multirow{2}{*}{$\begin{array}{l}\text { Monosporous } \\
\text { sporangium }\end{array}$} & shape & $\begin{array}{l}\text { elliptic, fusiform, ovoid, } \\
\text { pediculate, straite }\end{array}$ & $\begin{array}{l}\text { elliptic, fusiform, ovoid, } \\
\text { pediculate, straite }\end{array}$ \\
\hline & size & $15-26.5 \times 6-12.5 \mu \mathrm{m}$ & $12-20 \times 6-14 \mu \mathrm{m}$ \\
\hline Zygospore & $\begin{array}{l}\text { shape } \\
\text { size }\end{array}$ & not observed & not observed \\
\hline
\end{tabular}

**described by Kwon and Hyeong (2005)

\section{Acknowledgements}

The authors wish to acknowledge and express their gratitude to Proctor (PC), All India Coordinated Research Project (AICRP) on Vice Chancellor (VC), Indian Council of Agricultural Research (ICAR) for financial assistance for conducting the experiment and National Fungal Culture Collection of India - Ajrekar Mycological Herbarium (NFCCI-AMH) accession service of Agharkar Research Institute (ARI), for the identification of the pathogen.

\section{References}

Agrios G.N. 2005. Plant Pathology. 5th ed. Academic Press, San Diego, CA, USA: 434-435.

Boysen M., Borja M., del Moral C., Salazar O., Rubio V. 1996. Identification at strain level of Rhizoctonia solani AG 4 isolates by direct sequence of asymmetric PCR products of the ITS regions. Current Genetics 29 (2): 174-181. DOI: https:// doi.org/10.1007/s002940050033

Das S., Dutta S., Mandal B. 2017. First report of Choanephora cucurbitarum, causing leaf blight of hyacinth bean in India. Journal of Plant Pathology 99 (2): 533-543. DOI: http:// dx.doi.org/10.4454/jpp.v99i2.3899

Doyle J.J., Doyle J.L. 1987. A rapid DNA isolation procedure for small quantities of fresh leaf tissue. Physics Bulletin 19: 11-15.

Fransworth N.R. 1994. Ethnopharmacology and drug development. p. 42-51. In: "Ethnobotany and the Search for New Drugs" (D.J. Chadwick, J. Marsh, eds). Wiley, Chichester, New York, 90 pp.

Ghosh P., Mandal A., Golam Rasul M. 2013. A new bioactive ursane-type triterpenoid from Croton bonplandianum Bail. Journal of Chemical Sciences 125 (2): 359-364. DOI: https://doi.org/10.1007/s12039-013-0387-9
Kaul V. 1967. Distribution and dispersal of Croton sparsiflorus Morong. Journal of Indian Botanical Society 46: 154-159.

Kong J.M., Goh N.K., Chia L.S., Chia T.F. 2003. Recent advances in traditional plants drugs and orchids. Acta Pharmacologia Sinica 24: 7-21.

Kwon J.H., Hyeong J.J. 2005. Soft rot of eggplant (Solanum melongena) caused by Choanephora cucurbitarum in Korea. Mycobiology 33 (3): 163-165. DOI: https://doi.org/10.4489/ MYCO.2005.33.3.163.

Phillipson J.D. 1995. A matter of some sensitivity. Phytochemistry 38 (6): 1319-1343. DOI: https://doi.org/10.1016/0031$-9422(94) 00780-w$

Saroj A., Kumar A., Qamar N., Alam M., Singh H.N., Khaliq A. 2012. First report of wet rot of Withania somnifera caused by Choanephora cucurbitarum in India. Plant Disease 96 (2): 293. DOI: https://doi.org/10.1094/pdis-09-11-0801

Tamura K., Stecher G., Peterson D., Filipski A., Kumar S. 2013. MEGA6: Molecular evolutionary genetics analysis version 6.0. Molecular Biology and Evolution 30 (12): 2725-2729. DOI: https://doi.org/10.1093/molbev/mst197

Tapsell L.C. 2006. Health benefits of herbs and spices: the past, the present, the future. Medical Journal of Australia (4 Suppl.): $1-24$.

Tiwary K.P., Choudhary R.N., Pandey G.D. 1981. A new alkaloid, 3-methoxy-4,6-dihydroxymorphinandien-7-one, and norsinoacutine have been isolated from extracts of Croton bonplandianum. Phytochemistry 20 (4): 863-864.

Walther G., Pawlowska J., Alastruey-Izquierdo A., Wrzosek M., Rodriguez-Tudela J.L., Dolatabadi S., Chakrabarti A., de Hoog G.S. 2013. DNA barcoding in mucorales: an inventory of biodiversity. Persoonia - Molecular Phylogeny and Evolution of Fungi 30 (1): 11-47. DOI: https://doi.org/ $10.3767 / 003158513 \times 665070$

White T.J., Bruns T., Lee S., Taylor J. 1990. Amplification and direct sequencingof fungal ribosomal RNA genes for phylogenetics. p. 315-322. In: "PCR Protocols. a Guide to Methods and Applications" (M.A. Innis, D.H. Gelfand, J.J. Sninsky, T.J. White, eds). Academic Press, London, UK. DOI: https:// doi.org/10.1016/b978-0-12-372180-8.50042-1

WHO. 2001. Legal status of traditional medicines and complementary/alternative medicine: a worldwide review. World Health Organization, Geneva, 200 pp. 